\title{
Eduard Hanslick's Legacy in Moritz Geiger's Music Aesthetics ${ }^{1}$
}

\section{Martina Stratilková}

One of the most prominent representatives of early phenomenology, the Munich philosopher Moritz Geiger (1880-1937), dealt systematically with the problems of aesthetics. His previous years of study with a proponent of empathy aesthetics, the philosopher Theodor Lipps, clearly influenced the thematic direction of his writings, while he adopted the tenets of the phenomenological method. In the examples Geiger used in his aesthetic writings music occupies quite a significant position, or, more precisely, Geiger's explanations are, at certain points, construed alongside the arguments that Eduard Hanslick introduced in his famous essay On the Musically Beautiful (1854). Our aim is to inquire more deeply into this generally well-known and, in the context of Geiger's philosophy, quite significative relationship and show whether and at what moments Geiger developed Hanslick's argumentation further, at what points Geiger diverted from it, how consistently Hanslick's influence was accomplished and whether, in the acknowledgement of Hanslick's reasoning, the Kantian motifs were employed.

\section{Eduard Hanslick's Notion of Aesthetic and Pathological Perception of Music}

Eduard Hanslick argued in his core work Vom Musikalisch-Schönen [1854, On the Musically Beautiful] for the acknowledgement of such judgments about music as are founded on a demonstrable musical process and which distance themselves from overly objectivising tendencies (assuming an extra-musical meaning) and subjectivising tendencies (emphasising the emotional reactions of the listeners). So after a period when these views of music predominated, a true return "to the thing itself", to sounding and perceived music, took root. Like the authors of the first contributions to musical phenomenology (such as Mersmann), Hanslick

\footnotetext{
${ }^{1}$ The study was supported by the Research Support Foundation of the Faculty of Arts, Palacký University Olomouc, project FPVC2013/14 (Phenomenological Analysis of Music) and by the Czech Ministry of Education, Youth and Sports, project IGA_FF_2017_038 (Theory, History and Editing of Music from the $19^{\text {th }}$ to the $21^{\text {st }}$ Century).
} 
stated: "Aesthetic contemplation cannot rely on circumstances that lie outside of the artwork itself."

Hanslick's intellectual background has been explored deeply in a number of essays or even thematic conferences and continues to be so, which is evidenced in several important contributions published this year, including a new translation of Rothfarb and Landerer complemented by a lenghty introduction by these authors. Hanslick is usually considered a prominent $19^{\text {th }}$-century formalist aesthetician who based his music aesthetics on a Kantian ground in which he was also helped by Friedrich Herbart's aesthetics. However, the most recent scholarship (see Landerer's and Wilfing's treatises cited below) presents manifold doubts and complements these assumptions with other possible sources of Hanslick's theoretical stance. Though Hanslick surely had good knowledge of philosophical approaches to aesthetics, he could hardly have been deeply acquainted with individual systems. This enabled him, on the other hand, to employ elements of various approaches, even if they were quite disparate. With regard to our topic, we should stress Kant's inferences of disinterestedness in distinguishing beautiful arts and agreeable arts, ${ }^{3}$ leading to doubts about the position of music among them and generally about an appropriate aesthetic attitude. That is a motif extensively elaborated by Hanslick and later by Geiger as well.

The chapter Das ästhetische Aufnebmen der Musik gegenüber dem pathologischen [Aesthetic Compared to Pathological Perception of Music], in which Hanslick analysed the perception and experiencing of music, could have been inspirational for Geiger. It has to be noted that Hanslick, as a huge representative of music criticism, wanted to intervene in musical culture and the modes of listening. Hanslick distinguished here between a valuable artistic feeling, linked to pure perception of a work of art, and pathological intoxication, surrender to the music as a sensory stimulus which draws its extraordinary power from the musical material - a sound and motional character, which allegedly has a powerful impact on the nervous system. In the case of pathological listening, music acts non-specifically, like many other evidently non-artistic stimuli (such as drugs). Presenting "only sensuous stimuli," ${ }^{4}$ it circumvents the realm of the spirit and directly arouses an emotional feeling recruited from the regular repertoire of reactions common to

\footnotetext{
${ }^{2}$ Eduard Hanslick, "On the Musically Beautiful," in Lee Rothfarb, Christoph Landerer, Eduard Hanslick's On the Musically Beautiful: A New Translation (New York, NY: Oxford University Press, 2018), 66.

3 "The description 'agreeable art' applies where the end of the art is that the pleasure should accompany the representations considered as mere sensations, the description 'fine art' where it is to accompany them considered as modes of cognition." Immanuel Kant, Critique of Judgement, ed. Nicholas Walker and transl. James Creed Meredith (Oxford University Press, 2008), 134.

${ }^{4}$ Hanslick, "On the Musically Beautiful," 83.
} 
people; during pathological listening "music is used only as a means of promoting a certain mood in us". ${ }^{5}$ Music loses its distinctiveness in this way because a pathological listener is unattentive to the unique and detailed features of music and perceives music through a global emotion. In contrast, an aesthetic attitude can be seen where "aesthetic pleasure in a piece of music orients itself to its artistic value", ${ }^{6}$ where the individual peculiarities of a composition ervoke the spiritual conception: "Aesthetic contemplation should conceive music not so much as cause than as effect, not as producing but as product."

The relation to Immanuel Kant's aesthetics seems truly striking; together with Appelqvist we can claim that Hanslick followed Kant in several of his main postulates, which are: contemplation, the disinterestedness of the aesthetic attitude, conceptlessness and non-purposiveness of beauty. ${ }^{8}$ Nevertheless, though it was only Kant who included them in a system, individually they were quite widespread in the decades before him and Hanslick could have derived them from various philosophers. It is true that he cited Kant only once. Moreover, a selective proximity to other philosophical approaches has been suggested, mainly a closeness to Bolzano and Theodor Vischer. ${ }^{9}$ Wilfing ${ }^{10}$ emphasises one point in which he sees the strongest incongruity between Hanslick's stance and Kant's system: the notion of subjective universality. Though Appelqvist ${ }^{11}$ rightly pointed out Hanslick's view of artistic rules as being intuitively performed by an artist, providing him with creative freedom, according to Wilfing Bolzano's notion of artistic rules, which implied a sedimented historical process and social norms, should rather be considered here. ${ }^{12}$

\footnotetext{
${ }^{5}$ Ibid., 91.

${ }^{6}$ Ibid.

${ }^{7}$ Ibid., 92. For Kant the agreeable is attended "with a delight pathologically conditioned (by stimuli)". Cf. Kant, Critique of Judgement, 41.

${ }^{8}$ Hanne Appelqvist, "Form and Freedom: The Kantian Ethos of Musical Formalism," Nordic Journal of Aesthetics 22, no. 40-41 (2010-2011): 75.

${ }^{9}$ Cf. Christoph Länderer, Eduard Hanslick und Bemard Bolzano. Ästhetisches Denken in Österreich in der Mitte des 19. Jabrhunderts (St. Augustin: Academia 2004); Barbara Titus, "The Quest for Spiritualized Form: (Re)positioning Eduard Hanslick," Acta Musicologica 80, no. 1 (2008): 67-97.

${ }^{10}$ Alexander Wilfing, "Hanslick, Kant, and the Origins of Vom Musikalisch-Schönen," Musicologica Austriaca - Journal for Austrian Music Studies (June 2018) http://www.musau.org/parts/neue-articlepage/view/47

11 Appelqvist, "Form and Freedom," 81-82.

${ }^{12}$ Wilfing, "Hanslick, Kant, and the Origins," [10-11, 27]; See also Christoph Länderer, "Eduard Hanslicks Ästhetikprogramm und die österreichische Philosophie der Jahrhundertmitte," Österreichische Musikzeitschrift 54, no. 9 (1999): 17; Christoph Landerer and Lee Rothfarb, "Introductory Essay 3: Philosophical Background," in Eduard Hanslick's On the Musically Beautiful, ed. Rothfarb, Landerer, lxviii-lxix.
} 
Christoph Landerer ${ }^{13}$ compared Hanslick's emphatic distinction between the properties of the work and the feeling which it evokes in a person more specifically to the phenomenological reduction. Later he adopted a more moderate view, formulating Hanslick's orientation toward the object as a meeting point of a traditional normative approach in aesthetics with later trends toward phenomenology and analytical philosophy. On the other hand, if there is some normative assumption present in Hanslick's essay, Appelqvist argues, ${ }^{14}$ it does not apply to our musical judgements, but solely to our mode of listening. The musical structure should arise from musical logic or musical laws, but these are performed intuitively in the "pure contemplation", without reference to any concept.

Though Nicole Grimes ${ }^{15}$ appreciates the fact that the binary oppositions by which Hanslick's aesthetics have been grasped for a long time are not stressed any more, it is profitable to point out Hanslick's account of tones as being "fulfilled form" ${ }^{16}$ and the task of musical philosophy as being "to do research on which necessary intellectual determinants are linked with each musical element and how they are associated with one another." ${ }^{17}$ This spiritual dimension points to the Hegelian motifs articulated by Theodor Vischer, so that it is possible to label Hanslick's approach as an "alternative between Herbartianism (Zimmermann) and Hegelianism (Friedrich Theodor Vischer)"18 or title him as an "Empathetic Formalist". ${ }^{19}$ And while one can consider Jaroslav Stříteckýs assumption ${ }^{20}$ that Hanslick apprehended the musical work from the phenomenon, and not from the essence, from Hanslick's respect for phenomenal forms and from the (timidly expressed) respect for spiritual value it is possible to deduce some anti-reductionism (uniqueness of apparent spiritual meaning), generally inherent in phenomeno$\log y$.

${ }^{13}$ Christoph Landerer, "Ästhetik von oben? Ästhetik von unten? Objektivittät und 'naturwissenschaftliche' Methode in Eduard Hanslicks Musikästhetik," Archiv für Musikwissenschaft 61, no. 1 (2004): 43.

${ }^{14}$ Appelqvist, "Form and Freedom," 82-83.

${ }^{15}$ Nicole Grimes, "Introduction," in Rethinking Hanslick: Music, Formalism, and Expression, ed. Nicole Grimes, Siobhán Donovan and Wolfgang Marx (Rochester, NY: University of Rochester Press, 2013), 2.

${ }^{16}$ Hanslick, “On the Musically Beautiful," 112.

${ }^{17}$ Ibid., 50.

${ }^{18}$ Lothar Schneider, cit. by Wilfing, "Hanslick, Kant, and the Origins," [4].

${ }^{19}$ Rothfarb, Lee. "Nineteenth-Century Fortunes of Musical Formalism," Journal of Music Theory 55, no. 2 (2011): 193.

${ }^{20}$ Jaroslav Střítecký, "Předmluva [Foreword]," in Eduard Hanslick, O budebním krásnu (Praha: Supraphon, 1973), 29. 


\section{Geiger's Concept of Aesthetic Experience}

Moritz Geiger, who was teaching courses on aesthetics and in whose unpublished works we can find a treatise on the history of aesthetics, was surely well aware of various trends in that field, historical as well as contemporary. So it does not come as a surprise that he cited Eduard Hanslick, whose seminal thesis On the Musically Beautiful brought about a revolution of some kind in the style of presenting opinions in music aesthetics and provoked continuous disputations regarding the meaning of music, emotions in music and the question of true musical art and compositional mastery. Geiger cited Hanslick in his 1911 study on the consciousness of feelings ${ }^{21}$ and also mentioned him briefly in his 1913 study. ${ }^{22}$ But it is clear that Hanslick's argumentation concerning the possibilities of apprehension of what is beautiful in music resonated well with Geiger's reasonings.

Geiger took on Hanslick's ideas on music as early as 1911, when he discussed the nature of feelings in a study which outlined the framework of his later approach to aesthetics. It formed the starting point of his argumentation concerning aesthetic experience as he presented it in his treatise on aesthetic enjoyment, while later treatises, though still chiefly drawing on the initial thesis, elaborated in Zugänge zur Ästhetik (1928) and in Die Bedeutug der Kunst (1976),23 a posthumously published book, develop a concept of aesthetic values which touches on Geiger's late effort, existential philosophy.

Right away, in his early essay on the consciousness of feelings Geiger introduced a connection to aesthetic experience. Notably, he distinguished between emotional experience of an object and an experience originating in attention to emotion itself. He thus asserted the possibility of a change of conscious attitude - either toward the object, or toward the emotion (aroused by the object). The choice of the attitude is symptomatic of aesthetic perception, and presumably also of artistic production, as when perceiving a realistic landscape artwork, whether it is a painting or a poem, one has to assume an objective stance (gegenständliche Einstellung, Aussenkonzentration), while when perceiving artworks of other types, especially lyric poetry, the apprehension of the object weakens,

${ }^{21}$ Moritz Geiger, "Das Bewusstsein von Gefühlen," in Münchener Philosophische Abhandlungen. Th. Lipps zu seinem 60. Geburtstag gewidmet. Leipzig: Barth, 1911.

22 Moritz Geiger, "Beiträge zur Phänomenologie des ästhetischen Genusses," Jabrbuch für Philosophie und phänomenologische Forschung 1 (1913), 567-684.

${ }^{23}$ Moritz Geiger, Zugänge zur Ästhetik (Leipzig: Der Neue Geist, 1928); Moritz Geiger, Die Bedeutung der Kunst, Gesammelte, aus dem Nachlass ergänzte Schriften zur Ästhetik, ed. Klaus Berger and Wolfhart Henckmann (München: Wilhelm Fink Verlag, 1976; a translation of selected texts from Die Bedeutung der Kunst: Moritz Geiger, The Significance of Art. A Phenomenological Approach to Aesthetics, ed. and trans. Klaus Berger (Washington, D. C.: Center for Advanced Research in Phenomenology \& University Press of America, 1986). 
while the recipient becomes quite naturally open to the mood evoked in him (zuständliche Einstellung, Innenkonzentration). Both the object-oriented and the feeling-oriented attitudes thus seem to be appropriate in aesthetic perception. But Geiger further distinguished two types within the feeling-oriented attitude: inner concentration in the feeling and inner concentration on the feeling. ${ }^{24}$ In the first case one is wholly immersed in the feeling; one lives in it. In the second case, the recipient has the feeling before himself, he faces it: "The I and its mood, on which it is concentrated, stand one against another"; ${ }^{25}$ although the mood is not in the position of an intentional object, the I still lives on in the feeling. In aesthetic perception a mature attitude would consist of conscious experience of outer concentration; within inner concentration it is an attitude of sentimentality which applies to an enjoyable conscious feeling-oriented attitude, evolved, for example, while listening to a melancholy song.

The antinomy of enjoyable outer concentration and inner concentration is particularly obvious in the realm of music and can be detected in the character of the music itself, as well as in differing theoretical approaches. ${ }^{26}$ While a fugue by Bach requires outer concentration, Debussy's music could hardly be enjoyed within pure outer concentration. From among music aestheticians Geiger contrasted the views of Hanslick and August Wilhelm Ambros. Hanslick's assertion accepts only an attentive active listening of pure contemplation, while Ambros argued that music naturally arouses moods in the listener. And Geiger was willing to admit that this mode of perceiving music is more appropriate to modern music, such as, for example, that of Richard Wagner. It is also worth mentioning that he refused to take into account Richard Wagner's treatises because of their subject matter, which is not absolute music, but music together with words.

Geiger established fully his perspective of aesthetic issues in Beiträge zur Phänomenologie des ästhetischen Genusses [Contributions to the Phenomenology of Aesthetic Enjoyment]. Aesthetic enjoyment stems from adopting a special attitude toward the object: "whether I have aesthetic enjoyment or not is not at all based on the object, but on the type of attitude to it". ${ }^{27}$ And at the same time Geiger presented the characteristic of aesthetic enjoyment against the background of enjoyment in general because "enjoyment is an experience in which

\footnotetext{
${ }^{24}$ Innenkonzentration auf ein Gefühl - Innenkonzentration in einem Gefühl, zuständliche Einstellung auf ein Gefühl - zuständliche Einstellung in einem Gefühl. I use Mariano Crespo's translations "feeling-oriented attitude" and "object-oriented attitude". Cf. Mariano Crespo, "Moritz Geiger on the Consciousness of Feelings," Studia Phanomenologica 15, 2015, 385.

${ }^{25}$ Geiger, "Das Bewusstsein von Gefühlen,” 158.

${ }^{26}$ Ibid., $160-161$.

${ }^{27}$ Geiger, "Beiträge zur Phänomenologie des ästhetischen Genusses," 634.
} 
my ego is involved", ${ }^{28}$ it is "actually 'self-enjoyment", ${ }^{29}$ "I-centred". ${ }^{30}$ Though Geiger was aware of this inner involvement and concentration of enjoyment on self-experience, he conceded only such an experience as is traced by the object, not the ego with all its attributes (the personality of the recipient). In any case, in including the self in the experience, the enjoyment of the aesthetic situation surpasses enjoyment in general by virtue of the fact that "the ' $\mathrm{I}$ ' (Selbst) in the sense of that which pertains to me directly is eliminated". ${ }^{31}$ This "self-forgetting" ${ }^{2}$ suggests the contemplation of things as it also involves the aesthetic disinterestedness formulated by Kant. So on the one hand "each enjoyment undoubtedly engages I, is I-centred"; on the other hand "the I (Selbst) is eliminated from the aesthetic enjoyment." ${ }^{33}$

Aesthetic enjoyment may be induced only by a certain way in which the object is grasped, that which gives it in fullness (Fülle), in the presencing consciousness of perception or imagination. In an everyday situation we look at a thing primarily in the unity of its meaning: "immediately through the intuition of sense data", ${ }^{34}$ whereas in the aesthetic attitude the consciousness also focuses on the phenomenal richness in which the object is given "a ray of consciousness halts at the sensual data and takes an interest in the fullness - it is no longer interested in the "what" that appears in this fullness". ${ }^{35}$

It thus remains to ask whether the fullness mentioned by Geiger plays a role in the aesthetic attitude realised by some special role if it is already inherent in perception. Here the presence of "intuitive fullness" 36 forms only a necessary but not a unique aspect of aesthetic enjoyment. "When I see a tree, the object itself in fullness also stands before me clearly [...] If, on the other hand, I merely think of the object, this fullness is lacking in it." ${ }^{37}$

Another distinctive trait of the standpoint which the perceiver adopts towards an aesthetic object is contemplation (das Betrachten), which is free of any active and participatory dealing with the object and which is also defined by the distance toward the object, a sort of holding an object in a position in front of oneself: "the distance between I and the object", "holding in front of me" (Fernstellung

\footnotetext{
${ }^{28}$ Ibid., 613.

${ }^{29}$ Ibid., 617.

${ }^{30}$ Ibid., 612.

${ }^{31}$ Ibid., 652.

${ }^{32}$ Ibid., 652-653.

${ }^{33}$ Ibid., 652, 653.

${ }^{34}$ Ibid., 645.

${ }^{35}$ Ibid.

${ }^{36}$ Ibid., 644.

${ }^{37}$ Ibid., 646.
} 
von Ich und Gegenstand, Gegenüberhaltung). ${ }^{38}$ Taken negatively, this attitude does not allow the object to get closer to the perceiver, so it ensures "that the object itself does not enter me" ${ }^{39}$ Geiger ascribed the possibility of distance to all sensual modalities, but naturally he assigned a privileged position to sight and hearing. Whereas in the case of sight, distance is fundamental, hearing is somerwhat closer to the contact senses: "whereby contemplation is not given as evidently and purely as is the case for colours." ${ }^{40}$ This is because sounds are linked with the body; they "fill my ear". ${ }^{41}$ An auditory aesthetic object does not stand in front of the recipient, but it moves from the place of its source to the body of the listener. Thus the position of auditory modality has important consequences for musical experience. In outer concentration I find myself "inwardly directed to the object of experience, the melody". ${ }^{42}$ If, however, I am in inner concentration, "I do not actually experience the object, but the music stimulates my mood, and I focus on my mood and not the object." 43

As outer concentration is connected with distance, it is not effortless to achieve it. In inner concentration, distance is preserved in it only in those cases where it remains directed to the actual experience state ("inner concentration on the feeling"); then it is possible also to consider aesthetic enjoyment from various emotional states. This stance is not extra-aesthetic state, but rather pseudo-aesthetic. ${ }^{44}$ But an experience state may swallow up the recipient completely ("inner concentration in the feeling"), and then, in such a Dionysian state, "this experiencing in mood has nothing in common with any contemplation and thus with any aesthetic experience". ${ }^{45}$ And, according to Geiger, it is music which offers perception in which the recipient surrenders to his own emotions, which the work had merely kindled in him, and adopts a pseudo-aesthetic attitude.

He found support this partial condemnation in the words of Eduard Hanslick and revoked also his earlier assumption that Debussy's music must be experienced in inner concentration - any artwork has to be experienced in outer concentration, though of a differing kind. ${ }^{46}$

\footnotetext{
${ }^{38}$ Ibid., 632. Geiger chose terms characterising consciousness in its attitude towards the object, which the term distance - describing the remoteness between a subject and object (or rather a manifestation of this attitude), which is, of course, otherwise common - tends to conceal.

${ }^{39}$ Ibid.

${ }^{40}$ Ibid., 635.

${ }^{41}$ Ibid., 636.

${ }^{42}$ Ibid.

${ }^{43}$ Ibid., 637.

${ }^{44}$ Ibid., 639.

${ }^{45}$ Ibid., 640.

${ }^{46}$ When he mentioned a sunset atmosphere, he spoke of "empathizing contemplation" (einfühlende Betrachtung), ibid., 637.
} 
From the later treatises, Zugänge zur Ästhetik (1928) and other texts published in the edition of collected works Die Bedeutung der Kunst, one can deduce the culmination of Geiger's attitude, expressed mainly in the chapter Vom Dilettantismus im künstlerischen Erleben [On Dilettantism in the Artistic Experience], included in Zugänge and later also together with some unpublished texts in both the German and English edition of Geiger's selected writings. He described the danger of an inauthentic experience of art with a duality of terms describing aesthetic enjoyment: we approach the aesthetic value of a work in liking (Gefallen) and enjoyment (Genußen). Liking truly occurs as an evaluation of a work which also has opposing poles, and the subject is active in it. In contrast to this, experiencing in enjoyment has no value poles because it is a mere emotional reaction to a work to which the subject is passively exposed. Geiger also called it the aesthetics of effect. In a normal meeting of the recipient with the work, both types are applied in a differing ratio. But only liking is directed to the value as the quality of the work, whereas concentration on enjoyment tends to use the work as a means of attaining a pleasurable experience state in which the specificity of the artistic context is lost. So the aesthetics of effect cannot be considered wholly inauthentic, but naturally it is itself incomplete.

What really matters, is the attitude of the listener and the character of the music he experiences. Although by virtue of their nature the operas of Wagner may, compared to the music of Bach or Palestrina, ease the transition to inner concentration, this is still an "abuse" of music to evoke an emotional intoxication: "This contrast between objective and subjective music, however, has nothing to do with that between outer and inner concentration. Outer concentration is the proper attitude for every art", "inner concentration in the experience of music is in every case dilettantism." 47

He included in his reasoning concerning aesthetic experience this notion of dilettantism, which could be defined more broadly: "We shall speak of dilettantism in artistic experience whenever an experience which is inadequate for the work of art claims to be genuine artistic experience, when that claim is made for it by the experiencer himself." ${ }^{48}$ However if somebody uses music consciously for some extra-aesthetic end, it is not a matter of dilettantism. In later thoughts Geiger was more attentive to cultural context of art and its theory. While music is generally rather an art strongly appealing go subjectivity, we can identify in music history a grow of subjectivity from Renaissance counterpoint up to the music of Richard Wagner, representing a peak point of subjectivism. Because of that Geiger could state: "In no art does the dilettantism of experience in inner

${ }^{47}$ Geiger, The Significance of Art, 82, 83 .

${ }^{48}$ Ibid., 77. 
concentration celebrate such orgies as in music." ${ }^{49}$ At least Geiger could see the decay of this sentimentalist era during his time (in the 1920s). He also specified that there can be various forms of dilettantism. The era or rationalism led to inappropriate emphasis on understanding, while from the $19^{\text {th }}$ century on he discerned a type, which was arrived at by stressing emotional experience sentimentalism. In both of theses forms the absence of "aesthetic qualities and nothing else" ${ }^{" 50}$ can be detected because either emphasising the emotional effects of art or its intellectual grasp means to get beyond the aesthetic attitude, since true aesthetic experience resides in fullness through which aesthetic intuition is achieved. Similarly to Hanslick, who criticised approaches that were too subjectivising and too objectivising, he paid in his treatises more attention to the trend of subjectivising.

In other chapters from Zugänge, Oberfächen-und Tiefenwirkung der Kunst [translated for the English edition as Surface and Depth Effects of Art] and Die psychische Bedeutung der Kunst [translated as The Spiritual Significance of Art], Geiger was dealing with the significance of art for a human being, human life. He still cared for considering art in its pure form: "purely aesthetic effects", "the question of autonomous effects of art", which echoes Hanslickian rhetoric. ${ }^{51}$ However he aims to something else. Both knowledge and aesthetic experience are "based on the drive to make oneself master of the objective world." 52 "When we surrender ourselves to the object and let it enter into us, it becomes ours; it is spiritually incorporated in us and we become master of it." ${ }^{53}$ But aesthetic mastery of the world could be viewed as more valuable, since is it not mediated through concepts, and more importantly, it provides a subjective significance - it is experienced, affects our existence. Geiger continued to a more detailed analysis and in an appreciative allusion to Theodor Lipps he emphasised the role of vital elements, the structure of forces felt from within a human body, in aesthetic experience. And in this connection he reminded Eduard Hanslick, who accepted some positive areas of music expression - that of force and motion. "Even so pure a formalist as Hanslick could entirely keep from recognizing them." ${ }^{54}$ But the sphere of deeper spiritual values was beyond Hanslick's scope. Generally said, the spiritual in art stems from its formal aspect (eurhythmy principle) and the content as well (principle of imaging) and leads to "two ultimate values which

\footnotetext{
${ }^{49}$ Ibid., 82.

${ }^{50}$ Ibid., 109.

${ }^{51}$ Ibid.

${ }^{52}$ Ibid., 115.

${ }^{53}$ Ibid., 117.

${ }^{54}$ Ibid., 131
} 
our spiritual life strives for achieve a unity - the value of the individual and that of the universal." 55

Geiger's notion of the spiritual in art suggests that Geiger posited the aesthetic value as objective. This is really the case ${ }^{56}$ and it is quite strongly formulated in Geiger's discussion of Kant's theory of the taste judgement and the distinction between agreeable and beautiful arts. According to him Kant distinguished the agreeable and the beautiful, but he didn't make a difference between the two in their possibility of being judged objectively: "Kant observed correctly but interpreted wrongly. The judgement of beauty does indeed make a claim to universal validity." ${ }^{77}$ The judgement of the agreeable is only a "subjective reaction", but the judgement of the beautiful "admits of an objective justification". ${ }^{58}$ The analysis of value is attentive to various value elements and stresses intuitive operation, which also means that the process leads to the enrichment of experience. This analysis shows that "aesthetic judgements can very well have foundations, but not proofs." ${ }^{\prime 9}$ It is because while partial values, arising from various aspects of the artwork, can be analyzed, but on the contrary both aesthetic pleasure and aesthetic value can be grasped only in the totality of one's single experience. The position of Eduard Hanslick, aesthetician and critic, was surely closer in theses consequences to Geiger than that of Kant.

\section{Final remarks}

In all his key aesthetic writings Geiger draws support from Hanslick's descriptions of the aesthetic perception of music, as distinguished from mere potential to provide sensual pleasure. One of the crucial points for him was the definition of the aesthetic attitude, in which he regularly went back to Immanuel Kant and stressed his tenets of contemplation and disinterested pleasure. He was also aware of, and really touched upon, Kant's distinction between agreeable and beautiful arts, whereby "everything that pleases, and for the very reason that it pleases, is agreeable", ${ }^{60}$ which means that agreeableness appears in an attitude which is interested in the object just for the sake of the agreeable sensations it provides

\footnotetext{
55 Ibid., 127.

${ }^{56}$ Algis Mikunas, observing quite narrowly Geiger's appraisal of Kant's aesthetics, characterised his positions as “objectivism' without 'reductionism". Cf Algis Mickunas, "Moritz Geiger and Aesthetics," in Kaelin Eugene F., Schrag Calvin O. (eds) American Phenomenology. Analecta Husserliana, 26 (Springer, Dordrecht: Kluwer Academic Publishers, 1989), 43-57.

${ }^{57}$ Ibid., 102.

${ }^{58}$ Ibid.

${ }^{59}$ Ibid., 106.

${ }^{60}$ Kant, Critique of Judgement, 37
} 
and it is not linked to the unique features of the object. These would be accessible in contemplation, which is always linked to cognition. Moreover, Kant was ambivalent about whether to classify music among the agreeable or fine arts and both Hanslick and Geiger were sensitive to special features of music which make it more susceptible to being experienced in a sentimental, dilettantish way. But the phenomenological background supplied Geiger with a more delicate view of music's sensory material and its meaning for human life.

The distinction between agreeable and beautiful arts might have been inspirational for Hanslick, whose formulation and convincing descriptions of a distinguished music connoisseur brought a vivid argument to Geiger. On the other hand, Geiger's notion of outer and inner concentration mirrors Kant's polarity and so he was able to draw inspiration directly from him. The heritage of such "a strong couple" of thinkers dealing with this topic could have wielded some influence. Geiger was surely well acquainted with the aesthetics of Kant, whom he mentioned very often; in fact, he taught a special seminar about his Critique of Judgement. ${ }^{61}$ But, on the other hand, his phenomenological stance differed from the Kantian one and Kant's philosophy of beauty seemed to him quite outmoded in several respects. He especially criticised Kant for placing the emphasis on subjective experience in his notion of the "subjective universality" of a taste judgement. Still, according to Geiger, Kant considered aesthetic experience as resulting solely in enjoyment. He did not want to take Hanslick's view that music has no other meaning than its forms. But the turn toward feeling taken by Rousseau was, in his opinion, brought by Kant to the theory of aesthetics, where the notion of free play of the imagination suggests that contemplation is in fact not governed by the traits of the object that is being contemplated, it is not grasped. Both aesthetic enjoyment and aesthetic values reside in the psychological peculiarities of each recipient. Psychology can be applied to study various types of emotional experience or motivations for experiencing aesthetic objects generally. But it cannot provide us with understanding the nature of art or aesthetic experience. Such a psychologistic stance should be overcome.

For Geiger "The aesthetic attitude is not an end in itself. It is the necessary condition for values to be grasped, and for aesthetic values to be made accessible to the existential self." And these values would provide "fullness, richness, depth of genuine aesthetic experience". ${ }^{62}$ Hanslick could have been closer to Geiger's view in this respect because of his emphasis on the value of music, stemming from its conveying specific musical ideas. In these assertions Hanslick

${ }^{61}$ The seminar was highly esteemed by Walter Benjamin, who studied in Munich for a short period in 1915-1917. Cf. Peter D. Fenves, The messianic reduction: Walter Benjamin and the shape of time (Stanford: Stanford University Press, 2011), 7-9.

${ }^{62}$ Geiger, The Significance of Art, 209. 
was indebted to Vischer's aesthetics, the context of which was surely known to Geiger ${ }^{63}$ Hanslick's stronger premise of the objectivity of the value judgement and music criticism might also helped Geiger to hold his position against Kant's subjectivism.

The musicological debate about Hanslick's essay seems also to have been assimilated by Geiger: in his study on the consciousness of feelings he postulated two stances as formulated by Hanslick and Ambros: Hanslick accepted only an active and object-oriented approach, while Ambros also admitted a perception of music which is orientated towards the mood aroused by it. Only two years later Geiger revoked this assertion and added that every experience of an artwork requires outer concentration, though of a differing kind. When he was writing earlier on the consciousness of feeling he probably did not fully consider the consequences of his opinions from the point of view of aesthetic theory. His interest in the phenomenology of emotions could stand for Geiger's continual emphasis on aesthetic consciousness.

\section{Eduard Hanslick's Legacy in Moritz Geiger's Music Aesthetics}

\section{Abstract}

Moritz Geiger, Edmund Husserl's pupil, was the first phenomenologist to devote himself to the issues of aesthetics throughout all his life. Growing out of a background in psychological aesthetics, mainly the aesthetics of empathy, he was chiefly concerned with the study of aesthetic experience. The present article pays attention to Geiger's concept of aesthetic enjoyment and especially the position in it of music, while analysing the most important assumptions of Eduard Hanslick's music aesthetics as Geiger implemented them into his own reasoning. The paper shows that Geiger's position was mainly rooted in the Kantian formulation of the aesthetic attitude as it was echoed in Hanslick. Both Hanslick and Geiger were helped in their thoughts about the position of music among the arts by the role of perceptual parameters. While Geiger acquired a more differentiated position in classifying aesthetic perception over Hanslick's brusque distinction between the right (aesthetic) and inappropriate (pathological) experience of art, in the context of his seemingly puritan formalism he could also appreciate Hanslick's cautious claim about the ideas conveyed by music because his position later shifted toward positing the existential significance of art.

${ }^{63}$ Geiger was very well acquainted with theories of empathy, he even presented an elaborated paper on approaches to empathy at the 4th Congress of Experimental Psychology. In fact, similar values, namely depth and vital intensity, were emphasised by empathy aestheticians. 


\section{Odkaz Eduarda Hanslicka v hudební estetice Moritze Geigera}

\section{Abstrakt}

Moritz Geiger, žák Edmunda Husserla, byl první fenomenolog, který se zabýval otázkami estetiky po celý svioj život. Díky svému dobrému základu v psychologické estetice, hlavně v estetice vcítění, se věnoval prredevším studiu estetické zkušenosti. Aktuální studie se zaměřuje především na Geigerův koncept estetického požitku a zejména, jakou pozici v něm zaujímala hudba, přičemž analyzuje nejvýznamnější př̀edpoklady hudební estetiky Eduarda Hanslicka, jak je Geiger zahrnul do své vlastní argumentace. Článek ukazuje, že Geigerovo stanovisko vycházelo především $\mathrm{z}$ kantovské formulace estetického postoje $\mathrm{v}$ podobě, přijaté Hanslickem. Hanslick i Geiger si ve svých úvahách o pozici hudby mezi uměními vypomohli rolí perceptuálních vlastností. Zatímco Geiger dospěl k diferencovanějšímu pohledu při posouzení estetického vnímání než Hanslick se svým prísným rozlišením správného (estetického) a nevhodného (patologického) prožívání umění, v kontextu zdánlivě nekompromisního formalismu mohl ocenit Hanslickovy opatrné teze o idejích, vyjadřovaných hudbou, ostatně jeho vlastní pohled se později posunul směrem k předpokladu existenciálního významu umění.

\section{Keywords}

Moritz Geiger; Eduard Hanslick; Immanuel Kant; aesthetic experience; aesthetic attitude; sentimentalism

\section{Klíčová slova}

Moritz Geiger; Eduard Hanslick; Immanuel Kant; estetická zkušenost; estetický postoj; sentimentalita

Martina Stratilková

Katedra muzikologie FF UP

Univerzitní 3

77180 Olomouc, Česká republika

martina.stratilkova@upol.cz 